\title{
Prediction of Thermophysical Characteristics of Fuel Rods Based on Calculations
}

\author{
Stepan Lys *, Igor Galyanchuk, Tetiana Kovalenko \\ Lviv Polytechnic National University, 12 Stepan Bandera St., Lviv, 79013, Ukraine
}

Received: February 10, 2021. Revised: October 08, 2021. Accepted: November 04, 2021.

(c) 2021 The Authors. Published by Lviv Polytechnic National University.

\begin{abstract}
The paper analyzes operating conditions, thermophysical characteristics were calculated as applied to WWER1000 fuel rods in a four-year cycle for unified core. The paper gives a summary of models for calculating gas release, pressure of gases within fuel rod cladding, fuel swelling and thermal conductivity, fuel-cladding gap conductance. The thermophysical condition of fuels in a reactor core is one of the main factors that determine their serviceability. The stress-strained condition of fuel claddings under design operating conditions is closely related to fuel rod temperature, swelling, gas release from fuel pellets and the mode in which they change during the cycle and transients. Aside from this, those parameters are an independent goal of studies since their ultimate values are governed by the system of design criteria.
\end{abstract}

Keywords: reactor; calculation; thermophysical properties; thermal conductivity; gas release; fuel rod.

\section{Introduction}

Determination of fuel rod thermophysical condition is an important aspect of modelling behaviour and predicting fuel rod serviceability. Since most of the inter-fuel rod processes are substantially interrelated, the parameters of the thermophysical condition can be only calculated in the framework of the common code that integrally takes into account all main aspects of fuel rod behaviour, its mechanical condition included.

The thermophysical condition of fuels in a reactor core is one of the main factors that determine their serviceability. The stress-strained condition of fuel claddings under design operating conditions is closely related to fuel rod temperature, swelling, gas release from fuel pellets and the mode in which they change during the cycle and transients. Aside from this, those parameters are an independent goal of studies since their ultimate values are governed by the system of design criteria.

The design has to take into consideration all the main processes proceeding in fuel rods and demonstrate that they are unable to upset its serviceability. To corroborate the fulfillment of those requirements, four groups of design criteria are applied, namely, strength, strain, thermal physics and corrosion.

\section{Statement of the research problem}

Prediction of thermophysical parameters of a fuel rod is primarily based on the adequately determined temperature fields of fuel. In the START-3 code the temperature fields are found via solving the unsteady-state equation of thermal conductivity for a cylinder having internal heat sources. The solution of the problem in this statement is not technically complicated in itself; the important factors for the results to be credible are heat transfer via fuel-cladding gap, fuel pellet properties and their changes under irradiation. The highly important process is also a fission gas product release from fuel. The boundary conditions (temperature of cladding outer surface) are either specified as initial data or determined using a built-in block of a thermal hydraulics calculation of a channel.

*Corresponding author. Email address: lysss@ukr.net

This paper should be cited as: S. Lys, I. Galyanchuk, T. Kovalenko. Prediction of thermophysical characteristics of fuel rods based on calculations. Energy Engineering and Control Systems, 2021, Vol. 7, No. 2, pp. 79 - 86. https://doi.org/10.23939/jeecs2021.02.079 
The START-3 code participated in the international programme FUMEX [1] and showed itself one of the most credible code among the 19 participated codes. Nonetheless, the code development goes on, also as applied to thermophysical models.

The fuel rod thermophysical characteristics were computer modelled based on neutron-physics characteristics of 4-year fuel cycle with extra-charged 48 fuel assemblies (FAs) of which 30 FAs are in 3 year and 18 FAs are in 4 year operating cycles [2]-[5].

In this fuel cycle of operation at the power effect of reactivity, the following burn-up values are reached:

- discharged fuel assembly averaged value is $43.3 \mathrm{MW} \cdot$ day $/ \mathrm{kgU}$;

- maximal for FA value is $45.8 \mathrm{MW} \cdot \mathrm{day} / \mathrm{kgU}$;

- maximal for fuel rod value is $54.0 \mathrm{MW} \cdot$ day/kgU;

- for fuel rod pellet value is $59.4 \mathrm{MW} \cdot$ day $/ \mathrm{kgU}$.

With the account for the on power operation, the cycle time is $297 . .301$ effective days. The above initial data were used with the needed conditions of conservatism.

The specific loads were assumed with the account for the margin factor:

$$
Q_{0}=q_{1} \cdot k_{\text {eng }} \cdot k_{N}
$$

where $q_{1}$ is linear heat generation rate (LHGR) from neutron physics characteristics (NPC); $k_{\text {eng }}$ is engineering margin factor, 1.16; $k_{N}$ is coefficient of error in determining and maintaining the power, 1.04.

Burn-ups were established via extra-multiplying design values of NPC by margin factors that take into account the uncertainty of their calculations (see Table 1) [2].

Table 1. Margin factors for burn-up

\begin{tabular}{|l|l|l|l|}
\hline \multicolumn{1}{|c|}{ Element } & \multicolumn{1}{c|}{$\begin{array}{c}\text { Fuel burn-up from NPC, } \\
\text { MW-day/kgU }\end{array}$} & $\begin{array}{r}\text { Margin factors } \\
\left(1^{\text {st }} \text { periphery row/2 }\right. \\
\text { row/the rest array of fuel rods })\end{array}$ & $\begin{array}{c}\text { Calculated burn-up of fuel, } \\
\text { MW·day/kgU }\end{array}$ \\
\hline \hline FA & 45.8 & 1.05 & 48.0 \\
\hline Fuel rod & 54.0 & $1.12 / 1.08 / 1.07$ & $60.0 / 58.0 / 58.0$ \\
\hline Fuel pellets & 59.4 & $1.15 / 1.11 / 1.08$ & $68.0 / 66.0 / 64.0$ \\
\hline
\end{tabular}

Thus, with the aim of fuel rod validation at design burn-up, the calculations were implemented for higher values corresponding to the assumed margin factors.

The basic specific features of setting up the chart of the steady charge are:

- 30 of 48 fresh fuel assemblies are loaded into the core centre, the other 18 are at its periphery;

- the remaining vacant locations at the periphery are taken by fuel assemblies after four and two years of operation;

- 30 of 48 discharged fuel assemblies have operated for 3 cycles and 18 of them for 4 cycles.

The thermophysical characteristics were predicted using as an example fuel rods of the highest burn-up fuel assembly four year irradiated under steady operating conditions.

To have the full range of the thermophysical parameters of fuel rods within fuel assemblies, consideration was given to fuel rods No. 312 and 255 that are in the nearest position to the core center and have basic and profiled enrichment as well as to fuel rods No. 282 and 226 most distant from the core center and to fuel rod No. 6 located in the fuel assembly center (see Figure 1).

The thermophysical characteristics of fuels were predicted using the START-3 code [6].

\section{Aim of the research}

The aim of the work is thermophysical block of the code, including the verification array, as well as the results of design modelling the thermophysical condition of updated design fuel rods under conditions of the four-year operation in the WWER-1000 core. 


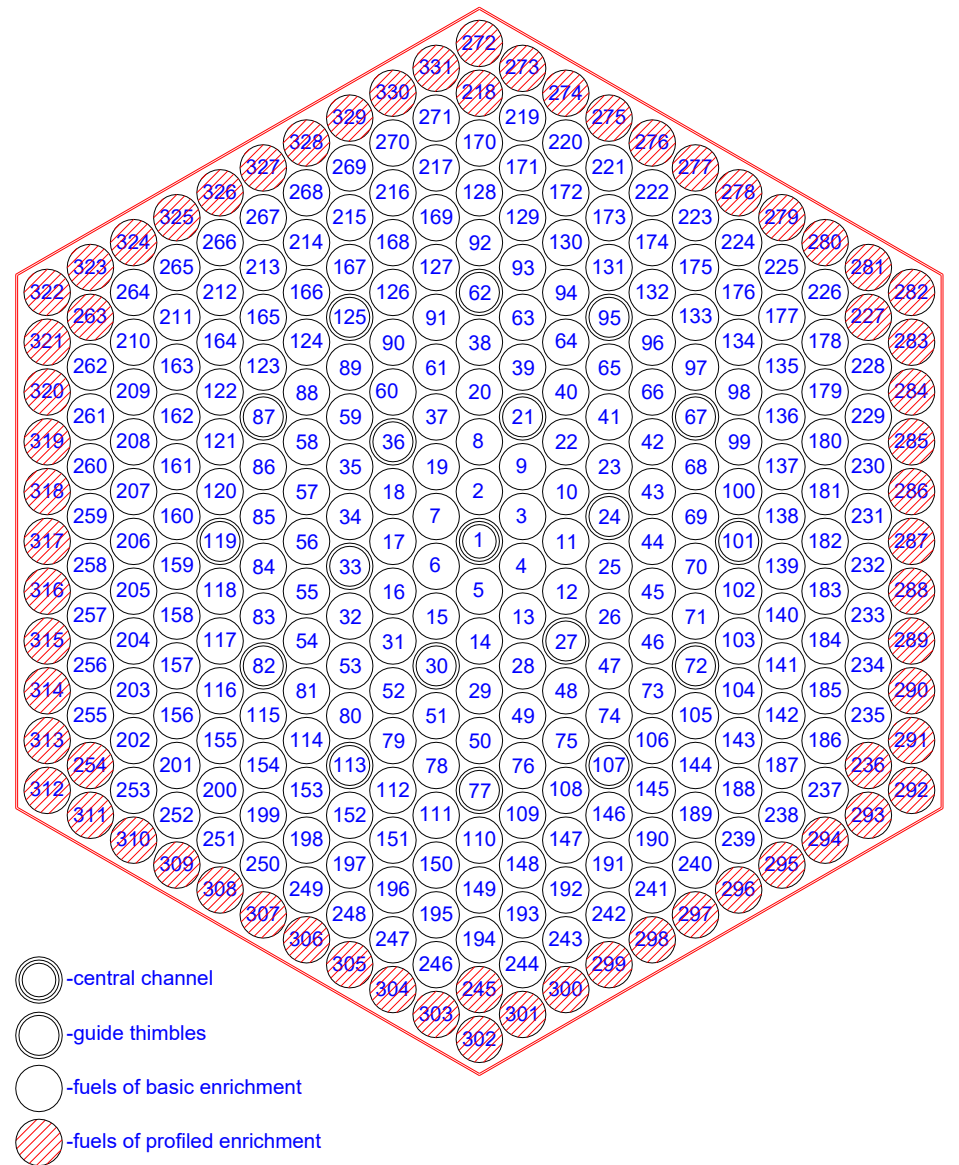

Fig.1. Schematic of FA component arrangement.

\section{Results and Discussion}

\subsection{Acceptance criteria}

The following acceptance criteria are applied for the validation of the thermophysical reliability of fuel rods: Ultimate temperature of fuel (TC1), Ultimate gas pressure within a fuel rod (TC2).

Ultimate temperature of fuel (TC1). The value of the fuel temperature is limited by the temperature of $\mathrm{UO}_{2}$ melting:

$$
T=T_{m e l t} .
$$

The temperature of pellet melting $\left(T_{\text {melt }}, \mathrm{K}\right)$ lowers down with fuel burn-up [7].

$$
T_{\text {melt }}=3113-3.2 \cdot B
$$

where $B$ is burn-up, MW.day/kgU.

The standard margin factor for this criterion is established to be $\mathrm{K}_{\mathrm{TC} 1}=1.1$ in view of the conservatism of the applied calculation approaches.

Ultimate gas pressure within a fuel rod (TC2). The pressure of gases within a fuel rod must not exceed the operating pressure of the coolant under normal operating conditions (NOC) and off-normal operating conditions (ONOC):

$$
P_{g}=P_{c}
$$

where $P_{\mathrm{c}}$ is pressure of coolant. 
The standard margin factor for this criterion is established to be $\mathrm{K}_{\mathrm{TC} 2}=1.1$.

\subsection{Provision of calculation conservatism}

The calculations are implemented using some conservative assumptions [2]:

- initial data on specific loads of fuels are given with account for uncertainty of their calculation;

- conservatively low properties of heat transport in a fuel rod (coefficient of heat transfer in a gap, thermal conductivity of fuel);

- conservative choice of fuel rod parameters to calculate temperatures (maximal fuel-cladding gap within tolerances, minimal fuel density, maximal fuel re-sintering);

- conservative choice of fuel rod parameters to calculate gas release (minimal fuel density, maximal fuel resintering, minimal grain size of fuel within tolerances);

- conservatism of fuel burn-up.

The input data for calculation that provide the necessary conservatism are listed in Table 2 [2], [8].

Table 2. Input data for calculation.

\begin{tabular}{|c|c|c|c|}
\hline Data & Range in conformity to specs & Assumed value & Notes \\
\hline Fuel density, $\mathrm{g} / \mathrm{cm}^{3}$ & $10.4-10.7$ & 10.4 & $\begin{array}{l}\text { Minimal value in tolerance } \\
\text { range }\end{array}$ \\
\hline Grain size of fuel, $\mu \mathrm{m}$ & $8-20$ & 8 & $\begin{array}{l}\text { Minimal value in tolerance } \\
\text { range }\end{array}$ \\
\hline Re-sintering, $\%$ & $\leq 0.4$ & 0.4 & Maximally provided \\
\hline Inner diameter of cladding, $\mathrm{mm}$ & $7.73^{+0.06}$ & $7.79 *$ & $\begin{array}{l}\text { Maximal value in tolerance } \\
\text { range }\end{array}$ \\
\hline Inner diameter of fuel, $\mathrm{mm}$ & $1.5^{+0.3}$ & 1.5 & $\begin{array}{l}\text { Minimal value in tolerance } \\
\text { range }\end{array}$ \\
\hline $\begin{array}{l}\text { Outer diameter of fuel pellet, } \\
\mathrm{mm}\end{array}$ & $7.57_{-0.03}$ & $7.54^{*}$ & $\begin{array}{l}\text { Minimal value in tolerance } \\
\text { range }\end{array}$ \\
\hline
\end{tabular}

* The averaged value of this parameter is used to calculate gas release and internal pressure of fuel rods.

\subsection{Calculation of maximal temperatures of fuel}

The maximal temperature of fuel was calculated to check the fulfillment of the design criterion TC1. Figure 2 gives the values of calculated LHGR in fuel rods with account for margin factors. Figure 3 shows variations in temperatures of the fuel center for all the studied fuel rods of FA vs. burn-up.

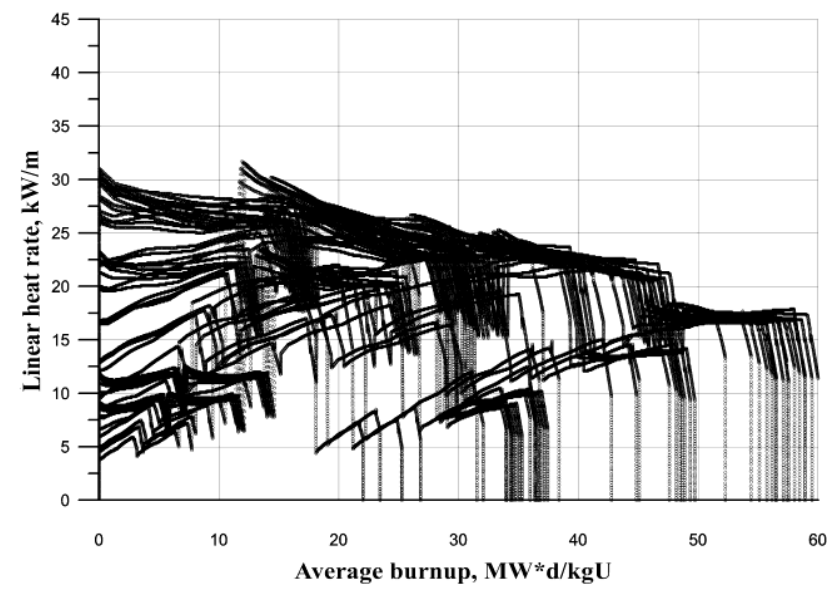

Fig.2. Linear heat generation rate vs burn-up.

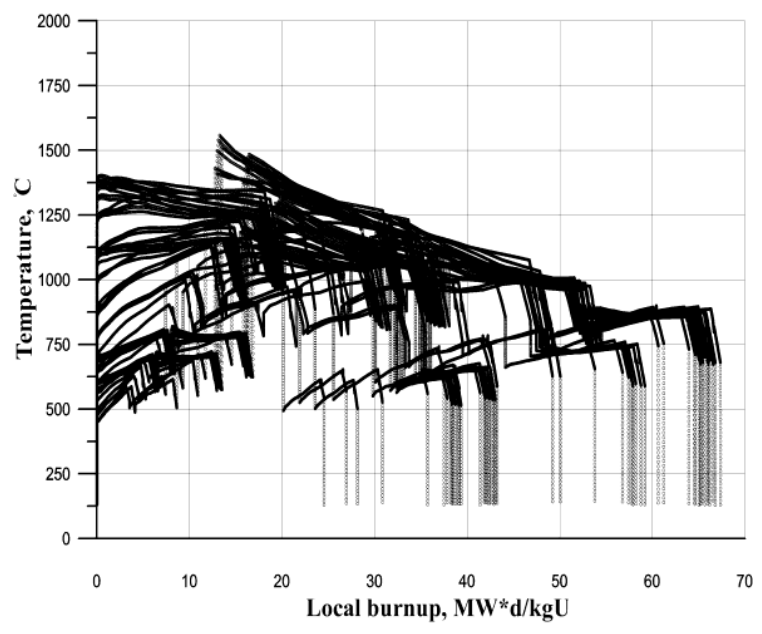

Fig.3. Temperature in the center of fuel vs burn-up.

The plot presents the temperatures in the fuel center of the calculated fuel rods along the height and in the process of burn-up. 
The calculation demonstrated that the maximal fuel temperature is reached in fuel rod No. 282 of the 4-year FA when relocated from the periphery to the core center and is equal to $1567{ }^{\circ} \mathrm{C}$.

Figure 4 illustrates variations in the temperature of the fuel center in fuel rod No. 282 per cycle in five sections along the height. The minimal margin factor for $\mathrm{TC} 1$ criterion is $\mathrm{K}_{\mathrm{TC} 1}=1.66$.

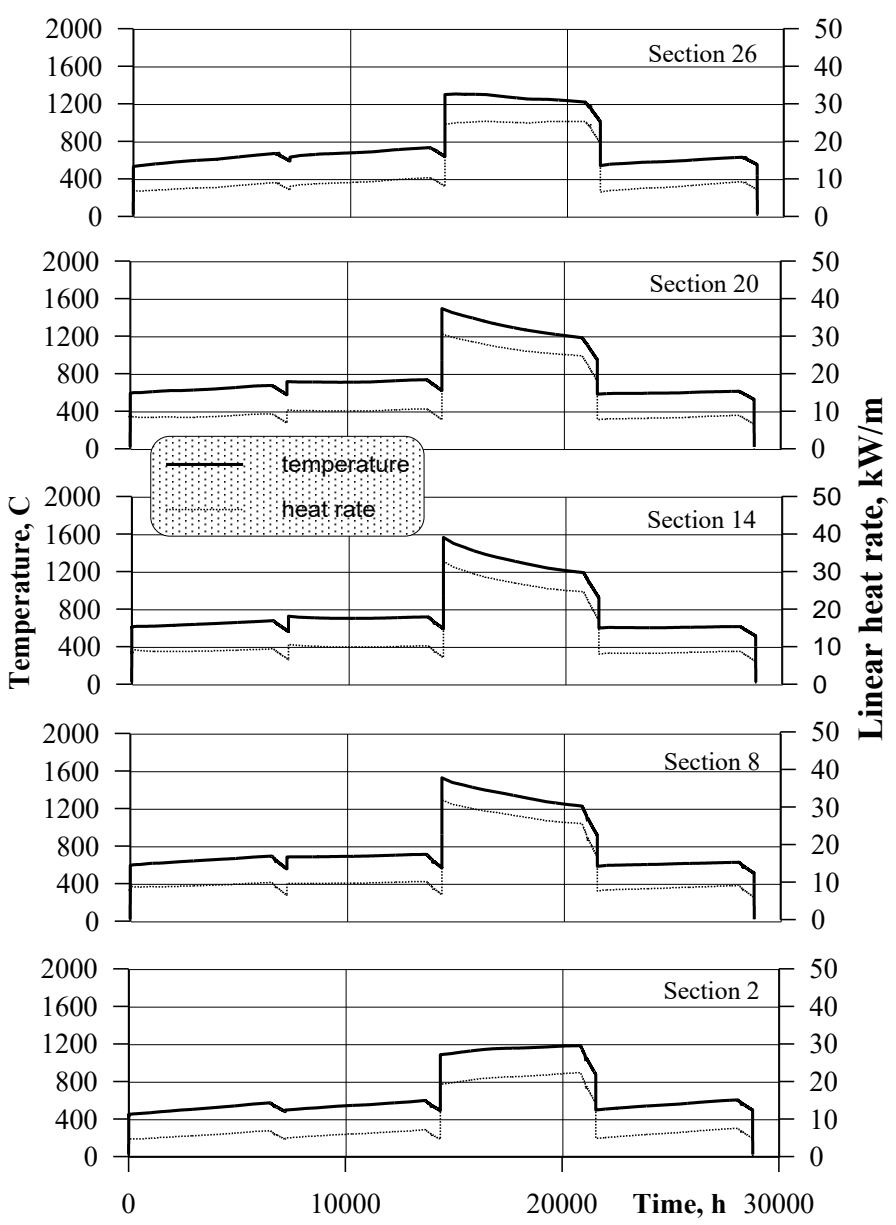

Fig.4. Temperature variations in fuel center of fuel rod No. 282 per cycle.

\subsection{Calculation of fission gas release and pressure within fuel rod}

The conservative calculations of FGR by fuel under the cladding evidenced the maximal gas release at the end of the cycle in the highest burn-up fuel rod No. 312 of the 4-year cycle fuel assembly that is $7.62 \%$ [2]. Figure 5 shows the calculated gas release in fuel rods against their average burn-up.

The pressure within the fuel rods of the symmetry sector fuel assemblies at the end of the cycle in "cold" and "hot" states is presented in figure 6. The maximal pressure in the "hot" state is demonstrated by fuel rod No. 312 and is $8.5 \mathrm{MPa}$. The minimal margin factor is $\mathrm{K}_{\mathrm{TC} 2}=1.84$.

The composition of the gas atmosphere within fuel rods at the end of the cycle is given in Figure 7.

Figures 8, 9 and 10 are plots illustrating the dynamics of variations in gas pressure and relative gas release in fuel rods No. 312, 6 and 282 of the 4-year cycle fuel assembly [2]. 


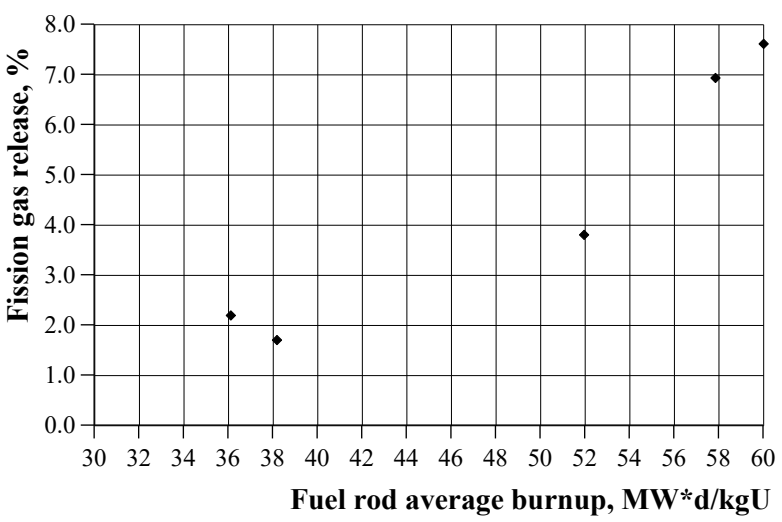

Fig.5. Gas release in fuel rods of 4 year cycle fuel assembly.

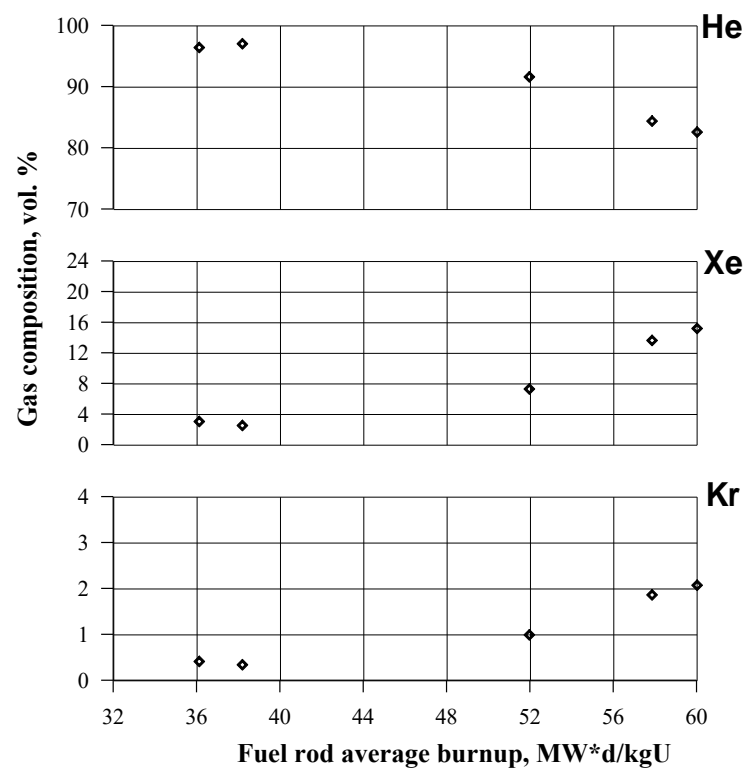

Fig.7. Composition of gas in fuel rods of 4-year cycle fuel assembly.

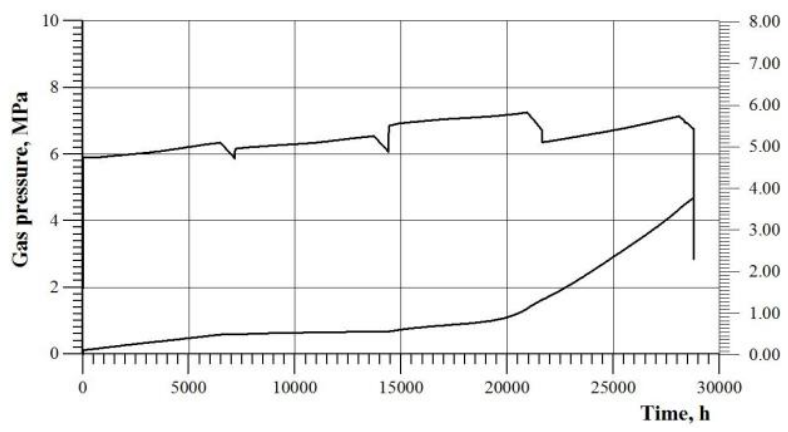

Fig.9. Gas release and pressure in fuel rod No.6 of 4-year cycle fuel assembly per cycle.

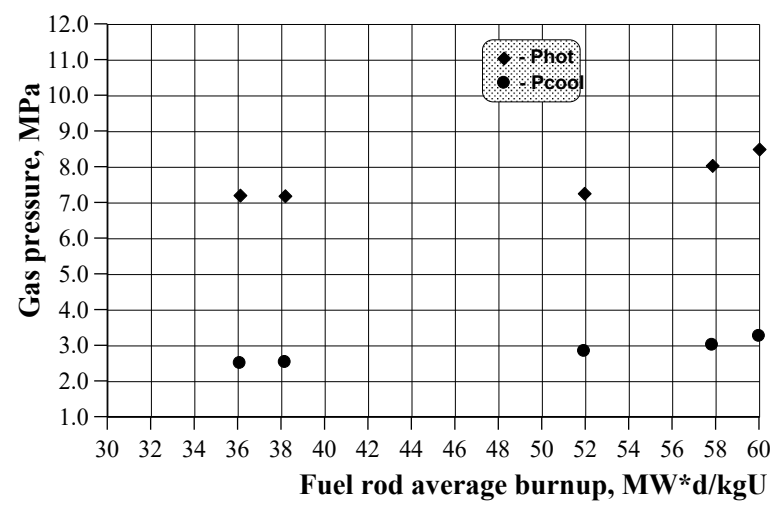

Fig.6. Gas pressure in fuel rods of 4-year cycle fuel assembly.

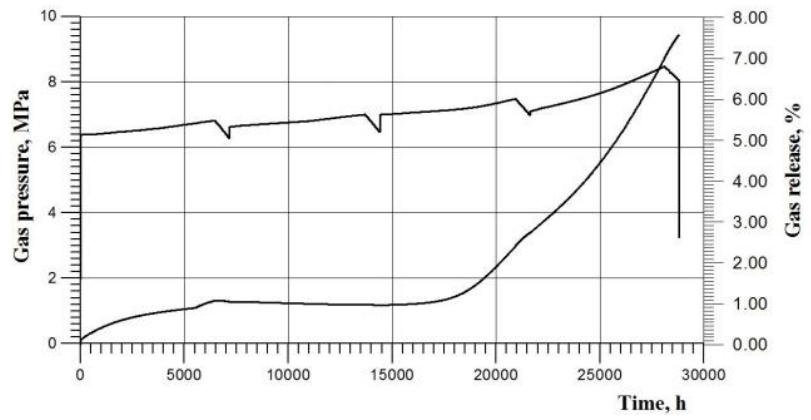

Fig.8. Gas release and pressure in fuel rod No.312 of 4-year cycle fuel assembly per cycle.

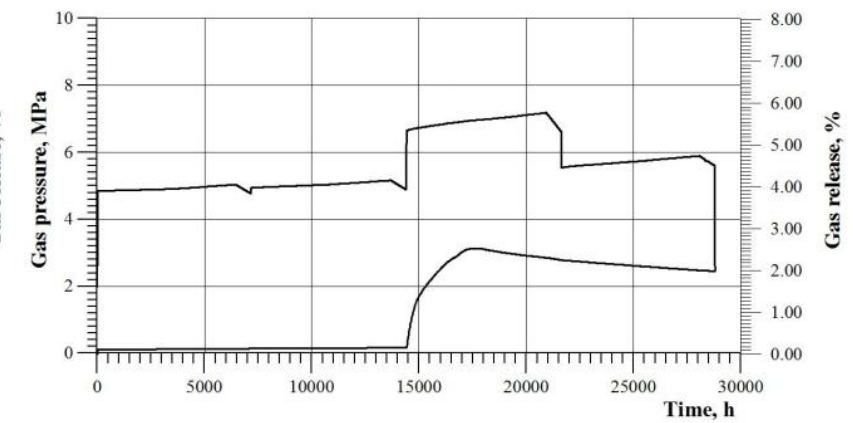

Fig.10. Gas release and pressure in fuel rod No.282 of 4-year cycle fuel assembly per cycle. 


\subsection{Calculation of gap thermal conductivity in WWER-1000 fuel rods}

The coefficient of heat transfer from fuel to cladding was calculated for the highest load fuel rod of the 4-year cycle fuel assembly. Figure 11 illustrates variations in the conductance of the fuel-cladding gap vs LHGR at the beginning of the cycle at the moment of the maximal irradiation effected resintering of fuel. Figure 12 shows variations in the gap conductance for the highest heat density section of a fuel rod per cycle.

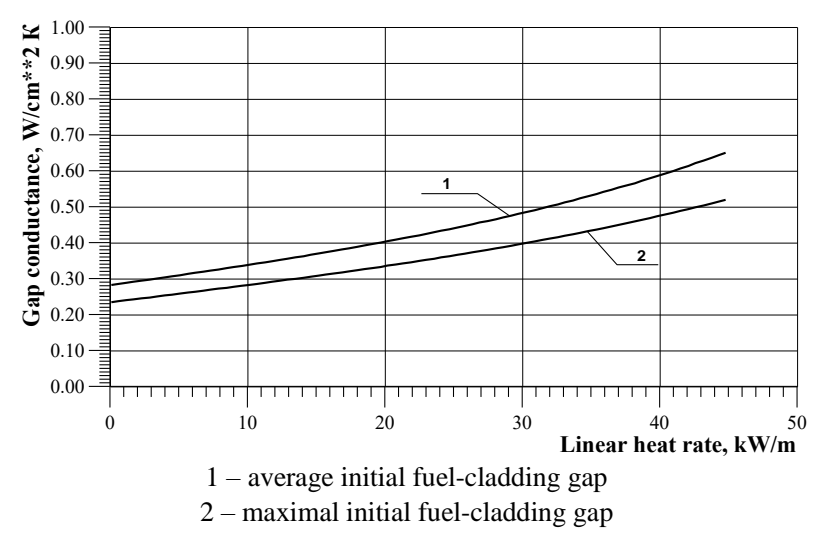

Fig.11. Conductance of gap vs LHGR early in cycle.

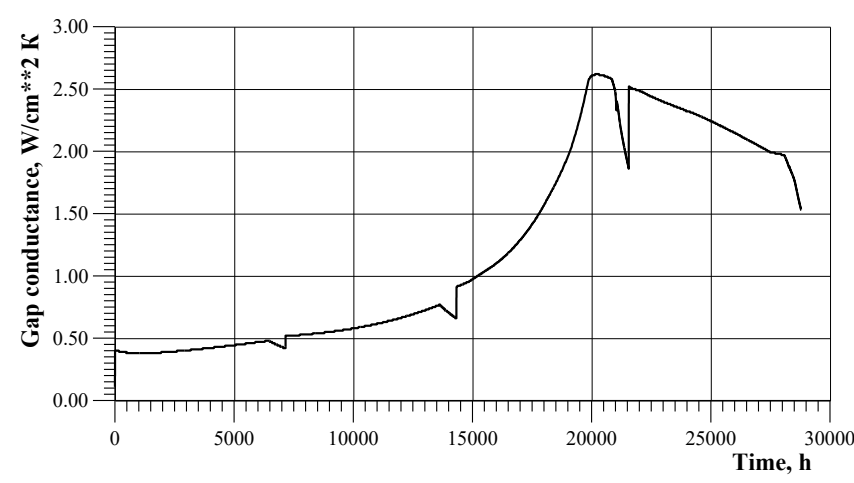

Fig.12. Variation in gap conductance per cycle.

The calculations were implemented for the maximal tolerable initial gap between fuel and cladding. A decrease in the gap conductance early in the cycle is explained by fuel resintering. After that, the dynamics of changes in the heat transfer from fuel to cladding is governed by varying levels of thermal loads, gap filling with the resultant contact between fuel and cladding, and dilution of the filler gas with fission gases.

\section{Conclusion}

The paper presents the basic principles of the analysis of the operating thermophysical characteristics of WWER1000 fuel rods using the START-3 code.

The presented results of computer modelling thermophysical characteristics of WWER-1000 4-year cycle fuel rods demonstrate that:

1.The maximal fuel temperature in fuel rods does not exceed $1567^{\circ} \mathrm{C}$ which is below the melting temperature of $\mathrm{UO}_{2}$ at the margin factor $\mathrm{K}_{\mathrm{TCl}}=1.66$;

2.The maximal gas release in fuel rods is $7.62 \%$;

3.The maximal pressure within fuel rods at the cycle end in "hot" state is $8.5 \mathrm{MPa}$ at the margin factor for TC2 criterion $\mathrm{K}_{\mathrm{TC} 2}=1.84$.

\section{References}

[1] "Fuel Modelling at Extended Burnup", IAEA-TECDOC-998, 1998.

[2] NPP "KUDANKULAM" Unit 1,2. Topical report "Prediction of fuel rod performance per cycle: temperature field, FGP release, swelling" SE VNIINM, 2001.

[3] Khvostov, Grigori, Novikov, Vladimir, Medvedev, Anatoli, and Bogatyr, Serguey. Approaches to modeling of high burn-up structure and analysis of its effects on the behaviour of light water reactor fuels in the START-3 fuel performance code. Japan: N. p., 2005.

[4] G. Khvostov, A. Medvedev, S. Bogatyr, "The dynamic model of grain boundary processes in high burn-up LWR fuel and its application in analysis by the START-3 code", Paper to the International Conference on WWER Fuel Performance, Modeling and Experimental Support, Albena-Varna, Bulgaria, September 29 - October 3, 2003.

[5] Medvedev A.V., Khvostov G.V. et al. "Prospects of Extended Burn-up (65 MW.day/kgU) Reached in WWER Fuels" International Conference, Electrostal, Russia, 8-10, June, 2000.

[6] Programme code START-3, Registration No. 76, Certificate of 22.09.97. 
[7] Azarov S.I. Calculation of the temperature in the fuel rod of a nuclear reactor / S.I. Azarov, G.A. Sorokin, T.V. Sorokina // Industrial heat engineering. -2005 . - T. 27, No. 5. - P. 70-75. (in Russian)

[8] Sorokina T.V. Comparison of calculation methods for determining the thermophysical state of the fuel rod of a nuclear reactor / T.V. Sorokina, S.I. Azarov, H.A. Sorokin // Nuclear and radiation safety. - 2008. - No. 1. - P. 26-31. (in Ukrainian)

\title{
Розрахункове прогнозування теплофізичних характеристик твелів
}

\author{
Степан Лис, Ігор Галянчук, Тетяна Коваленко
}

Національний університет «Львівська політехніка», вул. Степана Бандери, 12, Львів, 79013, Україна

\begin{abstract}
Анотація
Проведено аналіз умов експлуатації та розрахунки теплофізичних характеристик твелів ВВЕР-1000 в 4-х річному паливному циклі для уніфікованої активної зони. Представлено короткий опис моделей розрахунку газовиділення, тиску газів під оболонкою твелів, розпухання і теплопровідності палива, провідності зазору паливо-оболонка. Теплофізичний стан твелів в активній зоні реактора $є$ одним з основних факторів, що визначають ї працездатність. Напружено-деформований стан оболонок твелів в проектних режимах експлуатації тісно пов'язаний з рівнем температур в паливі, розпуханням, газовиділенням 3 паливних таблеток і характером їх зміни по кампанії і в процесі перехідних режимів. Крім того, ці параметри $\epsilon$ самостійною метою досліджень, так як їх граничні значення регламентуються системою проектних критеріїв. У роботі показані результати розрахункового моделювання теплофізичного стану твелів сучасної конструкції в умовах 4-х річної експлуатації в активній зоні реактора ВВЕР-1000.
\end{abstract}

Ключові слова: реактор; теплофізичні характеристики; теплопровідність; газовиділення; твел. 